\title{
MARRIAGE AND SEXUAL FIDELITY IN THE PAPYRI, PLUTARCH AND PAUL
}

\author{
G.W. Peterman
}

\section{Summary}

A well known double standard existed in the Roman perspective on sexuality within marriage: extra-marital sex is expected for men (within reason) but wholly condemned for women. Although pockets of dissent are evident, this double standard is generally accepted at all levels of society, being seen in papyri and in literary sources. If a married Roman couple were converted to Christianity, significant changes would need to take place because Paul teaches sexual equality within marriage.

It will be argued in this article that a Christian marriage as described by Paul approaches equality. ${ }^{1}$ On the other hand, the expectations and social standards of his time contained an explicit double standard: marital fidelity is expected of married women, but not necessarily for married men. Fidelity, especially for a Roman matron, was held as a sign of honour; a reflection of social status. ${ }^{2}$ Although this status was seriously threatened by the advent of the 'new woman', respectable women were still strongly castigated for extramarital sexual relationships. ${ }^{3}$ It was expected that men, however, would engage in extra-marital sexual relationships. We can appeal to the oft quoted Against Neaera (Demosthenes 59.122): 'We keep mistresses for our enjoyment, concubines to serve our person each day, but we have wives for the bearing of legitimate offspring and to be faithful guardians of the household.' Even though some

1 Thanks are due to Palm Beach Atlantic College School of Ministry for the generous assistance that made possible research for this article.

2 Thomas A.J. McGinn, Prostitution, Sexuality, and the Law in Ancient Rome (New York: Oxford University Press, 1998), 153.

3 For a helpful treatment on the new woman (on which see note 28 below) see Elaine Fantham, et al. Women in the Classical World: Image and Text (New York: Oxford University Press, 1994), 280-93. 
philosophers condemned this double standard, ${ }^{4}$ it was accepted by society at large.

We will assert, therefore, that conversion to Christianity would entail significant changes for the sexual relationship within marriage. We will look at the expectations seen in: (I) two papyrus marriage contracts from Egypt; (II) the advice to bride and groom written by Plutarch; and (III) the advice on marriage and sexuality given by Paul in 1 Corinthians 7:1-7.

\section{Papyri}

The papyri to be considered are P.Tebt. 104 (92 B.C.) and BGU 1052 (13 B.C.). These are examined owing to their good state of preservation and their explicit good behaviour clauses. ${ }^{5}$ Confirmatory references will also be made to additional contracts of later date. By way of prolegomena, we should note that such contracts are a window to common social expectation. This is the way things ought to be; a reflection of the social ideal. 'Each contract has its own stipulations and individual details that make it unique. Yet there are more similarities than differences, and, insofar as the various contracts stipulate the same rules of conduct for the wives and husbands, respectively, they reveal the ideal relationship between women and men in the society as a whole.' 6

\section{P.Tebt. 104 (92 B.C.)}

We shall skip over such details as the names of witnesses and the amount of the dowry, and only cite those portions of the contract that have bearing on the sexual relationship:

Apollonia shall live with Philiscus, obeying him as a wife should her husband, ${ }^{7}$ owning their property in common with

4 For example, Musonius Rufus says, 'men who are not wanton and immoral are bound to consider sexual intercourse justified only when it occurs in marriage...' (Cora Lutz, 'Musonius Rufus "The Roman Socrates" Yale Classical Studies 10 (1947), 87).

5 The lengthy and well preserved contract of A.D. 66 (P.Ryl. 154) will not be considered. The partners had cohabited for some time before the contract and thus most references to behavior are absent, stating only, 'let...the parties to the marriage live blamelessly together as in their previous married life.' P.Oxy. 267 (AD 37) also formalizes previous cohabitation. P.Mich. II.121 (AD 42), being an abstract of a contract, is only concerned with financial matters.

6 Sarah Pomeroy, Women in Hellenistic Egypt: From Alexander to Cleopatra (New York: Schocken Books, 1984), 84.

7 Because of its even closer temporal proximity to Paul and Plutarch we should note the presence of a very similar expression in the lengthy and 
him. All the necessaries and clothing and whatever else is proper for a wedded wife Philiscus shall supply to Apollonia, whether he is at home or abroad, in proportion to their means. It shall not be lawful for Philiscus to bring in another wife besides Apollonia, nor keep a concubine or boy, nor to have children by another woman while Apollonia lives, nor to inhabit another house over which Apollonia is not mistress, nor to eject or insult or ill-treat her, nor to alienate any of their property to the detriment of Apollonia.......In like manner it shall not be lawful for Apollonia to spend the night or day away from the house of Philiscus without Philiscus's consent or to consort with another man or to dishonour the common home or to cause Philiscus to be shamed by any act that brings shame upon a husband. 8

First, the responsibilities of Apollonia, the wife, will be considered. She should not spend a day or night away from home apart from Philiscus' consent (lines 27-28). ${ }^{9}$ This stipulation probably has a very practical dual purpose. First, the wife runs the household. It could not function in her absence. Second, a wife away from home might be expected to be engaging in extramarital sex. ${ }^{10}$ In addition one wonders if this has to do with fears that a protracted separation might raise questions among outsiders as to whether each spouse intended to remain married. ${ }^{11}$

Further, Apollonia should not be with another man $\left(\mu \eta \delta^{\prime} \alpha \ddot{\alpha} \lambda \lambda \omega\right.$

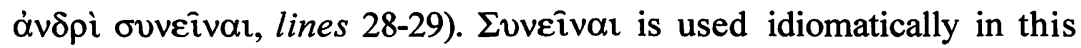
context meaning 'to engage in sex with' (cf. Plutarch Mor 139B, 142C; PSI I.64). Thus, sexual relationships with other men are expressly forbidden. ${ }^{12}$ She should not dishonour their home or shame Philiscus

elaborate, but unfortunately much mutilated P.Oxy. 265 (A.D. 81-95).

8 Text and translation are taken from A.S. Hunt and C.C. Edgar, Select Papyri I: Non-Literary Papyri, Private Affairs (Cambridge: Harvard University Press, 1988), 5-9.

9 'Roman Egyptian contracts, which drew on Ptolemaic conventions, sometimes specified that the wife would not spend a night away from the husband without his permission or that the husband would not take a concubine.' Susan Dixon, The Roman Family (Baltimore: Johns Hopkins University Press, 1992), 65-66.

10 Pomeroy, Women in Hellenistic Egypt, 97.

11 Susan Treggiari, 'Divorce Roman Style: How Easy and How Frequent Was It?' Marriage, Divorce and Children in Ancient Rome, ed. Beryl Rawson (Oxford: Clarendon Press, 1991), 36.

12 Hans-Albert Rupprecht, 'Marriage Contract Regulations and Documentary Practice in the Greek Papyri,' Scripta Classica Israelica 17 (1998), 64. 
(lines 29-30). Although the contract writer does not say so here, indeed he does not need to, a husband's honour is bound up with his wife's fidelity. 'The wife's adultery causes dolor to her husband.'13

What are the responsibilities of Philiscus, the husband? $\mathrm{He}$ should not bring in another wife. The difference in terminology is obvious and telling. Whereas Apollonia may not be with (бvveival)

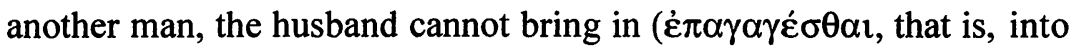
the home) another woman (as wife). He should not keep a concubine

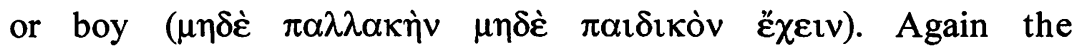
terminology is telling: the restriction is not against being with

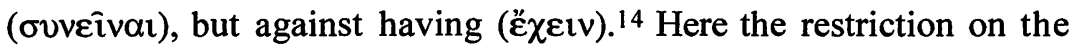
husband's sexual life means he cannot own a woman or a boy whom he uses for sexual favours. ${ }^{15}$ We should be clear that extramarital sex is not thereby forbidden. Rather, what is forbidden is the financial drain caused by the keeping of a $\pi \alpha \lambda \lambda \alpha \kappa \eta$ or $\pi \alpha 1 \delta \mathrm{t}$ kó . $^{16}$

Philiscus should not have children by another woman. The concern here is with heirs. In this contract the heirs must only be the biological offspring of Apollonia and Philiscus. It would appear that, if the husband were restricted from sexual relationships with other women, then this would be a point not worth mentioning. But if such encounters are not expressly forbidden, then a statement about children becomes necessary. He should not eject, insult or ill-treat Apollonia. If our reading of the contract is correct, we can deduce that, for the husband, extramarital sexual relationships do not constitute insulting treatment toward his wife.

\section{$B G U 1052$ (13 B.C.)}

The relevant portions of this rather shorter contract are as follows:

... and from now Apollonius son of Ptolemaeus shall furnish to Thermion as his wedded wife all necessaries and clothing in proportion to his means and shall not ill-treat her nor cast her

13 Susan Treggiari, Roman Marriage: Iusti Coniuges from the Time of Cicero to the Time of Ulpian (Oxford: Clarendon Press, 1991), 311.

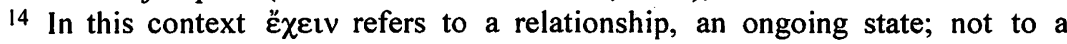
sexual act (see our comments on 1 Cor. 7:2 below).

15 On this practice compare Cicero's diatribe against Anthony (Phil. 2.45): 'No slave boy brought up in order to serve as an object of lust was ever in his master's grip as much as you were under Curio's spell.' On the connection between slavery and homosexual relations see Beert C. Verstraete, 'Slavery and the Social Dynamics of Male Homosexual Relations in Ancient Rome,' Journal of Homosexuality 5 (1980), 227-36.

16 Pomeroy, Women in Hellenistic Egypt, 96. 
out nor insult her nor bring in another wife, or he shall straightway forfeit the dowry increased by half ... and Thermion shall fulfill her duties towards her husband and their common life and shall not absent herself from the house for a night or a day without the consent of Apollonius son of Ptolemaeu nor dishonour nor injure their common home nor consort with another man ...17

With regard to the responsibilities of the husband we see these common requirements. He should not eject, ill-treat or insult her $(\mu \grave{\eta}$

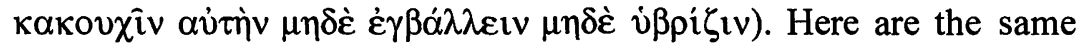
terms as found in P.Tebt 104, though in slightly different order: an indication that we are dealing with stock phrases. He should not

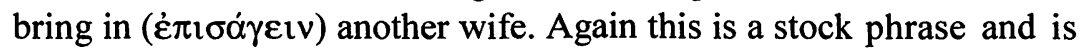
well-documented in the Augustan period. ${ }^{18}$

The responsibilities of Thermion, the wife, were also spelt out. She should not be absent from the home without Apollonius' consent, dishonour or injure their common home, or be with another man. Again there is the same significant difference in terms: the wife cannot be with (бuveival) another man, but the husband cannot bring in (غ่ $\pi \iota \sigma \dot{\gamma} \gamma \varepsilon \imath v)$ another wife (woman).

From this brief treatment of sexual expectations in two representative marriage contracts an obvious double standard emerges. The wife is restricted to sexual relations with her husband, but the husband is only restricted from relationships of a permanent nature (those brought into the common home) and from those that result in children. 19

\section{Plutarch}

Having examined the requirements agreed upon in these contracts, we are in a position to ask if there is a vast difference between its social expectations and the behaviour and expectations prescribed or encouraged by literary authors. We are confronted with the possible conflict: will the literary sources paint a picture much different from the non-literary sources? They do not. The same basic approach is confirmed by literary sources. Here comments will be restricted to Plutarch's Advice to Bride and Groom.

17 Text and translation are taken from Hunt and Edgar, Select Papyri I, 10-11.

18 See $B G U$ 1050, 1051, 1098, 1100 (all 30 B.C.-A.D. 14).

19 Rupprecht, 'Marriage Contract Regulations', 64. 
Though a native of Chaeronea, Plutarch's (c. A.D. 45-10) travels, study and political connections gained him extensive knowledge of things Greek and Roman. He draws on this background in his instruction to Pollianus and Eurydice, referring to Greek, Roman, Egyptian and Persian sources.

\section{Sexual desires}

As is common in the thinking of this period, the wife is to be passive in the sexual relationship. Although not on the topic of sexual intimacy at the time, Plutarch says that the wife models her mood on her husband's mood, she is to have no mood of her own (Mor 139F140A). This approach is also found in the sexual relationship. Plutarch cites with approval the saying of a young Spartan woman, who, being asked if she made advances toward her husband, responded: 'No, but he has made them to me.' In his view this is the attitude of the wise woman. She welcomes her husband's approaches. To reject them would be disdainful. But to take the initiative herself is just as bad, being meretricious and impetuous (140D; cf. Mor 242C). ${ }^{20}$ In other words, the virtuous wife is passive in the sexual relationship. ${ }^{21}$

Furthermore Plutarch states that the husband must realize that he cannot be with her both as a wife and as a lover (142C). This is in keeping with his view of sexual intimacy as functional: it helps maintain the marriage and brings forth legitimate children. It is not, however, a source of pleasure $(145 \mathrm{~A}){ }^{22}$

\section{Sexual fidelity}

Although Plutarch says both spouses should keep themselves from unlawful intercourse with others (144B), his reflections on the husband's potential immorality implies a double standard. We saw that in the two papyrus contracts there were different expectations

20 Compare Plutarch's encouragement of feminine passivity in the religious area: 'A wife ought not to make friends of her own, but to enjoy her husband's friends in common with him. The gods are the first and most important friends. Wherefore it is becoming for a wife to worship and to know only the gods that her husband believes in...(Mor 140D, LCL trans.).

21 'The good wife doesn't move (Lucr. 1268-77; Mart, 10.68.10; Plut. Conjugal Precepts 18).' Holt N. Parker, 'The Teratogenic Grid', Roman Sexualities, ed. J.P. Hallet and M.B. Skinner (Princeton: Princeton University Press, 1997), 55; cf. also p. 48: "Thus "active" is by definition "male" and "passive" is by definition "female" (emphasis original).

$22 \mathrm{Cf}$. Seneca, who states that "nothing is more shameful than to love your wife as if she was your mistress' (Adv. Iovin. 1.49). 
from the partners. So also with Plutarch. If the wife plays the passive role, as he seems to imply she should, no rivals to her husband will appear. She is after all, according to Plutarch, hiding herself when he is away (Mor 139C, 142C-D). Also he says that a wife should not become angry if the husband, owing to lack of control with regard to pleasure, indulges in some loose conduct with another woman such as a paramour or maidservant (Mor 140B, cf. 613A). She should instead reason that respect for her leads him to indulge his debauchery with another instead of abusing her by indulging it with her.

Similarly, if she suspects that her husband has a lover, it would be unwise for her to grow very jealous to the point of divorcing her husband. That position is, after all, exactly what her rival wants (Mor 144A).

\section{Conclusion}

Combining information gathered from P.Tebt. 104, BGU 1052 with the instructions given to bride and groom by Plutarch a clear picture begins to emerge. Sexual fidelity is conceived differently. The wife must not be with another man. The husband, although it might be ideal for him to engage in sex only with his wife, can have partners elsewhere. Similarly, the husband can initiate the sexual relationship in marriage. It is his role; he is the active partner. The wife is considered meretricious if she does so.

\section{Paul}

In answer to one of the questions set forward by the Corinthians, Paul cites one of their own beliefs that avoiding sexual intimacy ${ }^{23}$ with women is good.24 Some contend that this ascetic stance arose from the Corinthians' distorted spirituality. ${ }^{25}$ Particularly, many Corinthian women were denying their husbands. ${ }^{26}$ But just the

23 Ben Witherington III, Conflict and Community in Corinth: A SocioRhetorical Commentary on 1 and 2 Corinthians (Grand Rapids: Eerdmans, 1995), 175. He cites Plutarch Pompey II.3; Aristotle Pol 7.14 .12 and Josephus Ant 1.163 to the effect that 'touch' was a euphemism for having sexual relations with.

24 See the argument of Gordon Fee, The First Epistle of Paul to the Corinthians (Grand Rapids: Eerdmans, 1987), 275-76.

25 Richard B. Hays, The Moral Vision of the New Testament: Community, Cross, New Creation. A Contemporary Introduction to New Testament Ethics (San Francisco: Harper, 1996), 49.

26 See R. Scroggs, 'Paul and the Eschatological Women', Journal of the 
reverse could have been true. We know that in the first century there were a variety of views, not just on the morality of intercourse, but also on its healthfulness. Epicurus' view that intercourse is harmful had been taken over into the medical writers of the first-century. As a result many men, especially in the upper classes, had decided to live a life of continence. ${ }^{27}$ Soranus states that total abstinence is the ideal (Gyn. I.30-31). Some Corinthian men could view intercourse, even with their own wives, as unhealthy.

Paul says, however, that in order to avoid sexual immorality, each woman should have a husband and each man should have a wife. Further, each partner should be satisfy, and be restricted to, each other. ${ }^{28}$ Paul's comments here are unusual for their conflict with the active-passive dichotomy we see in the rest of literature. But here in 1 Corinthians 7 we see Paul set forward, in three ways, an egalitarian position on sexuality within marriage:

First, because of potential immorality, both men and women should have their own spouses; or simply, they should be married. This seems to be the best way to take verse 2 . The phrase does not mean 'acquire a wife', nor does it primarily refer to sexual relations (i.e. to 'have' sexually). It refers to the state of marriage ('having' a spouse), as later in this chapter and elsewhere (1 Cor. 7:29; Luke 20:28). ${ }^{29}$

Implicit in this advice is a range of additional assumptions. a) What happens outside of heterosexual marriage is sexually immoral and to be guarded against. The solution, for both parties, cannot be prostitutes, courtesans or extra-marital relationships. Even the

American Academy of Religion 40 (1972), 283-303 and M.Y. McDonald, 'Women Holy in Body and Spirit: The Social Setting of 1 Cor. 7', NTS 36 (1990), 161-81.

27 Aline Rousselle, Porneia: On Desire and the Body in Antiquity, Trans. Felicia Pheasant (Oxford: Basil Blackwell, 1988), 20. Rousselle goes on to state: 'Doctors who belonged to this school claimed that men who abstained from sex were taller and stronger that other men' (Porneia, 72).

28 Besides common Jewish concern for Gentile immorality, Paul may be combating the indulgence of the 'new women': '...a new kind of woman appears precisely at the time of Cicero and Caesar: a woman in high position, who nevertheless claims for herself the indulgence in sexuality of a woman of pleasure' (Fantham, Women in the Classical World, 280).

29 Other examples of this usage include Diodorus Sicilus 32.15.5 (Teres, a Thracian chieftain, is said to 'have' a wife); 3.32 .1 (the Trogodytes 'have' their wives in common): neither of these texts is about acquiring a wife, nor are they primarily about sexual intercourse. Compare Pausanias 1.7.3, 9.5.10, 9.17.6; Dio. Hal. 11.28.4; Diod. Sic. 10.20..1; 12.18.1; Philo LA 3.236; Epictetus 4.1.159; Diochrysostom 20.19. 
allowed abstinence, later mentioned, can only be temporary in order that lack of self-control might not lead to immorality. (b) Both sexes need to have a safeguard against this immorality. (c) The need for marriage, in order to avoid porneia, is not attributed to lack of virtue. Even the lack of self control mentioned later in the passage is not explicitly set in a derogatory context but in the context of some have one gift from God, some another (1 Cor. 7:7).

Second, Paul's egalitarian approach is seen in that each spouse should fulfil obligations to the other. In this context the obligations are understood to be sexual. This likewise assumes that there are responsibilities with both.

Third, each spouse has authority over the body of the other. ${ }^{30}$ Those who are familiar with Greek and Roman ways of thinking should find this comment surprising, if not astonishing. ${ }^{31}$ and Witherington rightly comments that Paul's '...egalitarian treatment of the rights of each partner is remarkable and would have amounted to a serious qualification of the status quo.' 32

Others have noted that there is a difference between Paul and Plutarch in this matter of sex and sexual desire in marriage. 'Paul advocates in 1 Corinthians 7 a reciprocity of rights and duties in the marriage relationship that presumes the equality of husbands and wives...' ${ }^{33}$ Abstinence is possible, and then it should be ended so that the partners can come back together. ${ }^{34}$

\section{Conclusion}

Literary and non-literary sources concur in describing a sexual double standard in first-century Roman marriage. The husband is active; the wife is passive. Marriage and its sexual side is for the

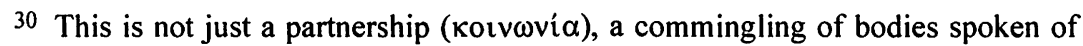
by Plutarch (Mor 140F), for he goes on to say that the husband is in control as the soul has control of the body (Mor 142E).

31 Coming close to Paul's thought, however, is Musonius who states that husbands and wives share 'all things in common between them, and nothing peculiar or private to one or the other, not even their own bodies' (Lutz, 'Musonius', 88-89).

32 Witherington, Conflict and Community, 175.

33 Kathleen O'Brien Wicker, 'Mulierum Virtutes (Moralia 242E-263C),' Plutarch's Ethical Writings and Early Christian Literature, ed. Hans Dieter Betz (Leiden: E.J. Brill, 1978), 117.

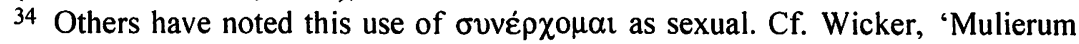
Virtutes', 132, citing Plutarch Mor. 254B, Matthew 1:18. 
procreation of legitimate children. Extramarital sexual partners are not allowed the woman; they are understood to exist for the man.

A very different picture emerges in Paul. Marriage provides the place for legitimate expression of sexuality. Sexual relations are a good activity in their own right and not simply the means of maintaining the marriage fellowship or producing children (as Plutarch says). Indeed, 'nothing is said about the procreative purpose of sex'. ${ }^{35}$ Husband and wife are on equal levels: each one has sexual authority over the other.

If a couple native to the first-century Mediterranean world were converted to Christianity, what changes, if any, would need to take place in the marriage bed? The changes might, depending on the variables of each individual, need to be considerable. First, neither spouse can avoid sex under a cloak of virtue. Indeed, sex is not about one's personal virtue but it is about one's obligation to the other partner. Second, questions might need to be asked about the purpose of marriage: is it first and foremost for the production of legitimate children and then secondarily for concord? Third, the spouses are sexually equal. A double standard must not exist.

35 Hays, Moral Vision, 51. 